\title{
THE RESPONSES OF GROWTH PERFORMANCE, DIGESTIBILITY AND BLOOD BIOCHEMISTRY OF CHICKENS TO THE DOSE AND ADMINISTRATION METHOD OF ENZYMES
}

\author{
A. S. El-Shafey ${ }^{1}$; Asmaa Sh. Elnaggar ${ }^{1}$ and M. I. El-Kelawy ${ }^{2}$ \\ ${ }^{1}$ Department of Animal and Poultry Production, Faculty of Agriculture, Damanhour University, Egypt. \\ ${ }^{2}$ Department of Poultry Production, Faculty of Agriculture, New Valley University, Egypt.
}

(Received 16/6/2021, accepted 1/8/2021)

\section{SUMMARY}

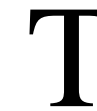

The aim of this study was to investigate the responses of growth performance, digestibility and blood biochemistry to the dose and administration method of enzymes. A total of 150 unsexed 1-dold Arbor Acres broiler chickens were divided equally among 5 dietary treatments with 6 replicates per treatment and five chickens each. All experimental groups were fed the same basal diet and given 5 multienzyme treatments: The $1^{\text {st }}$ group, the control group, did not receive multienzyme supplementations. The $2^{\text {nd }}, 3^{\text {rd }}, 4^{\text {th }}$ and $5^{\text {th }}$ groups were given multienzyme in water at 100 and $150 \%$ of the recommended dosage in drinking water given either continuously or intermittently methods, respectively. In the continuous method, the multienzyme is added to the water over the day. While, in intermittently method, the multienzyme is added to the water over the day followed by day off during the $1^{\text {st }}$ through the $35^{\text {th }}$ days of age. The addition of multienzyme either at 100 or $150 \%$ to water improves the growth performance and nutrient digestibility i.e. dry matter, crude protein and ether extract of broiler chickens compared with the control. However, $100 \%$ of multienzyme resulted in the best growth performance than that $150 \%$ multienzyme group. Intermittently administration exhibited significantly better growth performance and nutrient digestibility i.e. dry matter and NFE than those given multienzyme with continuously administration way. There were no significant effects of the multienzymes dose and the administration methods on carcass characteristics and blood biochemical constituents except triglycerides and creatinine. In conclusion, broilers received multienzymes at $100 \%$ intermittently in water exhibited significantly higher growth rate and significantly the best FCR. Production index was also the best of this group.

Keywords: Broilers, multienzyme, administration method and dose of enzyme.

\section{INTRODUCTION}

The use of enzymes in corn soybean diets for broilers is essential as to overcome the anti-nutritional factors even in non-vicious grains and protease inhibitors as will, which might limit nutrient digestibility's in the gut (Slominski, 2011 and Yegani and Korver, 2013). Chicken broilers is still unable to take advantage of 400-450 kcal of energy per kilogram of diet because its non starch polysaccharides (NSP) content which impede digestion of nutrients by broilers due to the shortage or absence of digestive enzymes capable of the hydrolyze of NSP (Cowieson, 2010). The use of NSP enzymes may be desired to hydrolyze of the anti-nutritional of ingredients to attain the best performance and profit from these diets (Slominski, 2011). Enzymes supplementation in broiler diets increasing activities of digestive enzyme (Alagawany et al., 2017) and improved the endogenous enzyme production thus improves the absorption of nutrients by the chickens (Angel et al., 2011).

The usage of enzymes in the feeding of broilers has enhances feed digestibility, minimizing the antinutritional effects and promoting the productivity indexes (Attia et al., 2003 and Hooge et al., 2010), the digestibility rates (Fafiolu et al., 2015 and Zeng et al., 2015).And improved growth performance (Attia et al., 2014a; Fafiolu et al., 2015 and Williams et al., 2014and 2018), survival rate (Abdel-Hafeez et al., 2016), reduce the pollutant potential of excreta (Costa et al., 2008), improved the economic efficiency (Attia et al., 2008 and El-Serwy et al., 2012) and gut ecology (Cowieson, 2010 and Attia et al., 2014b). However, the effect of multienzyme counted on dietary composition and enzyme type (Attia; 2003; Abudabos, 2012 and Attia et al., 2014a). This study aimed to investigate the responses of growth performance, digestibility and blood biochemistry of broilers to the dose and administration method of enzymes. 


\section{El-Shafey el al.}

\section{MATERIALS AND METHODS}

The study was carried out at the Al-Bostan Experimental Poultry Farm, Department of Animal and Poultry Production, Faculty of Agriculture, Damanhour University, Egypt.

\section{Experimental design and dietary treatments:}

One hundred and fifty-one-day-old Arbor Acres broiler chicks were randomly distributed into five treatment groups. Each treatment group consisted of six replicates of 5 unsexed birds each. All experimental groups were fed the same base diet and were given 5 multienzyme treatments: The $1^{\text {st }}$ group, the control group, did not receive multienzyme supplementations. The $2^{\text {nd }}, 3^{\text {rd }}, 4^{\text {th }}$ and $5^{\text {th }}$ groups were given multienzymes in water at 100 and $150 \%$ from recommended dosage in drinking water given either continuous or intermittent methods, respectively. In the continuous method, the multienzyme is added to the water over the day. While in intermittent method, the multienzyme is added to the water over the day followed by day off during the $1^{\text {st }}$ through the $35^{\text {th }}$ days of age. The experimental diets were formulated to meet requirements of broiler chickens according to NRC (1994). The multienzyme (Galzym ${ }^{\circledR}$ produced by Textan company and imported by El Nehesi company, it is a combination of a group of exogenous and fibrolytic enzymes consisted of, cellulase:100000000 unit, xylanase 1500000 unit, lipase 6500 unit, alpha amylase 250000 unit, protease 400000 unit and Pectinase 30000 unit). The recommended dose of enzymes is $1 \mathrm{ml} / 3 \mathrm{~L}$ water. The composition of the experimental diets is presented in Table (1).

Table (1): Ingredients and chemical composition of the experimental basal diets fed during the experiment stages.

\begin{tabular}{|c|c|c|}
\hline \multirow[b]{2}{*}{ Item } & \multicolumn{2}{|c|}{ Standard diets } \\
\hline & Starter (1-21d) & Grower $(22-35 d)$ \\
\hline \multicolumn{3}{|l|}{ Ingredients (g/kg) } \\
\hline Yellow corn & 512.3 & 518.1 \\
\hline Rye & 0 & 50 \\
\hline Soybean meal ( $44 \% \mathrm{CP})$ & 328 & 244 \\
\hline Dicalcium phosphate & 18.00 & 16.00 \\
\hline Limestone & 10.00 & 10.00 \\
\hline $\mathrm{NaCl}$ & 3.00 & 4.50 \\
\hline Full fat soybean meal & 100 & 130 \\
\hline Vit+min premix ${ }^{1}$ & 3.00 & 3.00 \\
\hline L-Lysine & 1.00 & 1.90 \\
\hline DL-Methionine & 2.00 & 2.50 \\
\hline Vegetable oil & 22.70 & 20.00 \\
\hline Total & 1000 & 1000 \\
\hline \multicolumn{3}{|c|}{ Calculated or determined composition $(\mathrm{g} / \mathrm{kg})$ : } \\
\hline Dry matter ${ }^{2}$ & 864 & 880 \\
\hline Crude protein $(\mathrm{CP})$ & 227 & 209 \\
\hline $\mathrm{CP}$ & 221 & 210 \\
\hline $\mathrm{ME}(\mathrm{Kcal} . / \mathrm{Kg})^{3}$ & 3018 & 3055 \\
\hline Crude fat, ${ }^{2}$ & 61 & 65 \\
\hline Crude fibre $^{3}$ & 40.2 & 37.2 \\
\hline Crude fibre $^{2}$ & 36.1 & 35.5 \\
\hline $\mathrm{NFE},{ }^{3}$ & 625 & 640 \\
\hline Calcium $^{3}$ & 8.58 & 8.45 \\
\hline Available phosphate $^{3}$ & 4.07 & 3.78 \\
\hline Methionine $^{3}$ & 5.48 & 5.71 \\
\hline Methionine+cystine $^{3}$ & 9.10 & 9.05 \\
\hline Lysine $^{3}$ & 13.18 & 12.53 \\
\hline Ash, ${ }^{2}$ & 51.1 & 53.5 \\
\hline
\end{tabular}

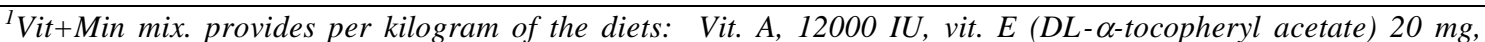
menadione $2.3 \mathrm{mg}$, Vit. D3, $2200 \mathrm{ICU}$, riboflavin $5.5 \mathrm{mg}$, calcium pantothenate $12 \mathrm{mg}$, nicotinic acid $50 \mathrm{mg}$, Choline $250 \mathrm{mg}$, vit. $B_{12} 10 \mu \mathrm{g}$, vit. $B_{6} 3 \mathrm{mg}$, thiamine $3 \mathrm{mg}$, folic acid $1 \mathrm{mg}$, d-biotin $0.05 \mathrm{mg}$. Trace mineral $(\mathrm{mg} / \mathrm{kg}$ of diets): $\mathrm{Mn} 80 \mathrm{Zn} \mathrm{60,} \mathrm{Fe} 35, \mathrm{Cu} 8$, selenium $0.1 \mathrm{mg} .{ }^{2}$ Analyzed values. ${ }^{3}$ Calculated values. 
Animal housing and management: Chicks were raised in battery brooders. Each replicate was kept in a cage $(30 \times 35 \times 45)$. Chicks had full access to feed and water during the experimental period. The housing temperature was $32^{\circ} \mathrm{C}$ during the $1^{\text {st }}$ week and declined gradually by $2^{\circ} \mathrm{C}$ each week and was then stabilized at $25^{\circ} \mathrm{C}$ until slaughter. A light schedule was $23 \mathrm{~h}$ light until $7^{\text {th }}$ day followed by $20 \mathrm{~h} \mathrm{light}$ from $8^{\text {th }}$ day to through the experimental period until 3 day before slaughter test (8-35 days of age).

Experimental procedures and growth performance measurements: Broilers in each replicate were weighed $(\mathrm{g})$ at 1,21 and $35 \mathrm{~d}$ of age, and the body weight gain (BWG,g/chick) was calculated. Feed intake (FI) was recorded for each replicate (g/chick) and thereby feed conversion ratio (FCR, g feed/g gain) and survival rate (SR, 100 - mortality rate) during the periods from 1-21, 22-35 and 1-35 d of age were calculated.

Apparent digestibility of dry matter (DM), crude protein (CP), ether extract (EE), crude fiber (CF) and ash was done according to (Aggoor et al., 2000). The DM, CP, EE, CF and ash of feeds and excrement were determined according to (AOAC, 2004) and expressed on DM basis.

Carcass characteristics measurements: At $35 \mathrm{~d}$ of age, six broiler chicks (3 males and 3 females) from each group were slaughtered after 8 hours fasting, processed and the weight of carcass and internal organs were taken and expressed as (\%) of live body weight (LBW).

Blood sampling and laboratory analyses: At slaughtering, six blood samples per treatment were collected in clean non-heparinised tubes. The serum was separated by centrifugation at $1500 \mathrm{x} \mathrm{g}$ for 10 minutes at $4^{\circ} \mathrm{C}$, and stored at $-18^{\circ} \mathrm{C}$ until analysis. The serum profiles were determined using commercial diagnostic kits (Diamond Diagnostics Company, Cairo, Egypt). Glucose concentration (mg/dl) was measured according to Trinder (1969). Total protein ( $\mathrm{g} / \mathrm{dl}$ ) was measured according to Henry et al. (1974), albumin (g/dl) was measured according to Doumas (1971), globulin (g/dl) was measured according to Coles (1974). The activities $(\mu / \mathrm{l})$ of the alanine aminotransferase (ALT) and aspartate aminotransferase (AST) enzymes were determined according to the method described by Reitman and Frankel (1957). In addition, serum samples were assigned for determination of creatinine and urea (Bartles et al., 1972), triglycerides (Fossati and Prencipe, 1982), total cholesterol (Stein, 1986), high density lipo-protein, HDL (Lopez-Virella, 1977), while low density lipo-protein (LDL) was determined according to (Friedewald et al., 1972).

\section{Statistical analysis:}

The statistical analysis was performed using a completely randomized design and all data collected were subjected to analysis using a two-way ANOVA procedure (Statistical Analysis System (SAS), 2002). The statistical model included the effects of the dose of the multienzymes $(0,100$ and $150 \%)$, method of administration (continuously vs. intermittently) and their interactions according to the following model: $Y_{i j k}=\mu+D_{i}+A M_{j}+(D \times A M)_{i j}+e_{i j k}$

Where $Y_{i j k}=$ observed value ; $\mu$ overall mean ; $D_{i}=$ doses effect; $A M_{j}=$ administration method effect; $(D \times A M)_{i j}=$ interaction between the two effects; $e=$ random error. Before analysis, all percentages were subjected to logarithmic transformation $\left(\log _{10} x+1\right)$ to normalize data distribution. The differences among means were determined using Duncan's new multiple range test (Duncan, 1955).

\section{RESULTS AND DISCUSSION}

\section{Growth and Feed:}

The effect of different dose of multienzyme given in water continuously or intermittently on the production performance of broiler chickens are summarized in Table (2). The results indicate that BWG during the periods from 1-21 and 1-35 days of age and FCR during all experimental periods were significantly affected by the dose of the enzyme, method of administration, and the interaction between them. The intermittent addition of multienzyme at $100 \%$ to water improves the BWG during the periods from 1-21 and 1-35 days of age and FCR during the periods from 1-21, 22-35 days of age and 1-35 days of age compared to other treatments. In addition, enzyme supplemented continuously at 100 and $150 \%$ as well as 100\% intermittent increases BWG during the periods from 1-21 and 1-35 days of age and improved FCR during the periods from 1-21, 22-35 and 1-35 days of age compared to the control group. However, FI of broiler chickens during most of the experimental periods was insignificantly affected by the dose of the multienzyme, supplementation method and the interaction between the dose of the enzyme and the administration method except for enzyme supplemented continuously increased FI compared to the control group during the periods from 1-35 days of age. 


\section{El-Shafey el al.}

Table (2): Effect of different dose of multienzymes given in water continuously or intermittently on growth performance in broiler chicks during the starter and growing-finishing periods ${ }^{1}$.

\begin{tabular}{|c|c|c|c|c|c|c|c|c|c|}
\hline \multirow{2}{*}{$\begin{array}{l}\text { Treatment } \\
\text { effect }\end{array}$} & \multicolumn{3}{|c|}{ Body weight gain (g) } & \multicolumn{3}{|c|}{ Feed intake $(\mathrm{g})$} & \multicolumn{3}{|c|}{ Feed conversion ratio ${ }^{2}$} \\
\hline & $1-21 d$ & $22-35 d$ & $1-35 d$ & $1-21 \mathrm{~d}$ & $\begin{array}{l}22- \\
35 d\end{array}$ & $1-35 d$ & $1-21 \mathrm{~d}$ & $22-35 d$ & $1-35 d$ \\
\hline \multicolumn{10}{|c|}{ Effect of enzyme dose } \\
\hline Control & $567 \mathrm{c}$ & 1108 & $1675 c$ & 898 & 2105 & 3003 & $1.58 \mathrm{a}$ & $1.90 \mathrm{a}$ & $1.79 a$ \\
\hline $100 \%$ & $711 \mathrm{a}$ & 1184 & $1895 \mathrm{a}$ & 1010 & 2065 & 3075 & $1.42 \mathrm{c}$ & $1.74 \mathrm{c}$ & $1.62 \mathrm{c}$ \\
\hline $150 \%$ & $685 b$ & 1166 & $1851 b$ & 1017 & 2093 & 3110 & $1.48 \mathrm{~b}$ & $1.79 b$ & $1.68 b$ \\
\hline \multicolumn{10}{|c|}{ Effect of administration method } \\
\hline Control & $567 \mathrm{c}$ & 1108 & $1675 \mathrm{c}$ & 898 & 2105 & $3003^{b}$ & $1.58 \mathrm{a}$ & $1.90 \mathrm{a}$ & $1.79 \mathrm{a}$ \\
\hline Con & $686 b$ & 1163 & $1848 b$ & 1019 & 2104 & $3123^{\mathrm{a}}$ & $1.48 \mathrm{~b}$ & $1.81 \mathrm{~b}$ & $1.68 \mathrm{~b}$ \\
\hline Int & $710 \mathrm{a}$ & 1188 & $1898 \mathrm{a}$ & 1009 & 2054 & $3063^{\mathrm{ab}}$ & $1.42 \mathrm{c}$ & $1.73 \mathrm{c}$ & $1.61 \mathrm{c}$ \\
\hline \multicolumn{10}{|c|}{ Interaction between enzyme dose and administration method } \\
\hline Control & $567 \mathrm{~b}$ & 1108 & $1675 \mathrm{c}$ & 898 & 2105 & 3003 & $1.58 \mathrm{a}$ & $1.90 \mathrm{a}$ & $1.79 \mathrm{a}$ \\
\hline $100 \%$ Con & $686 b$ & 1159 & $1845 b$ & 1022 & 2102 & 3125 & $1.49 \mathrm{~b}$ & $1.81 \mathrm{~b}$ & $1.69 b$ \\
\hline $100 \%$ Int & $736 a$ & 1210 & $1946 a$ & 998 & 2028 & 3025 & $1.35 \mathrm{c}$ & $1.67 \mathrm{c}$ & $1.55 \mathrm{c}$ \\
\hline $150 \%$ Con & $685 b$ & 1167 & $1851 b$ & 1014 & 2106 & 3120 & $1.48 \mathrm{~b}$ & $1.80 \mathrm{~b}$ & $1.68 b$ \\
\hline $150 \%$ Int & $685 b$ & 1166 & $1851 b$ & 1020 & 2081 & 3101 & $1.48 \mathrm{~b}$ & $1.78 \mathrm{~b}$ & $1.67 \mathrm{~b}$ \\
\hline RMSE & 22.11 & 40.84 & 32.04 & 44.05 & 74.91 & 57.80 & 0.032 & 0.037 & 0.021 \\
\hline \multicolumn{10}{|c|}{ Probability level } \\
\hline Dose & 0.015 & 0.333 & 0.005 & 0.714 & 0.411 & 0.187 & 0.0004 & 0.0080 & 0.0001 \\
\hline Method & 0.021 & 0.181 & 0.002 & 0.642 & 0.150 & 0.032 & 0.0004 & 0.0001 & 0.0001 \\
\hline Interaction & 0.021 & 0.168 & 0.002 & 0.446 & 0.469 & 0.134 & 0.0004 & 0.0017 & 0.0001 \\
\hline
\end{tabular}

Con=Continuous; Int= intermittently

${ }^{1}$ Number of observation $=6$ replicates per subgroup of each treatments.

${ }^{a b c}$ Within columns (for each effect), means not sharing similar superscripts are significantly different at $P=0.05$.

\section{Apparent digestibility of nutrients and European production index:}

Data concerning the effects of the dose of the enzyme and the administration method on the apparent digestibility of the nutrients of broiler chicks are shown in Table (3). Only the dose of the multienzyme had a significant effect on the digestibility of DM, CP and EE. The addition of multienzyme (100 or $150 \%$ ) to water improves the digestibility of DM and CP of broiler chickens compared with the control, and $100 \%$ multienzyme had the best digestibility of DM and CP. However, there were no significant effects due to the dose of the multienzyme on the apparent digestibility of CF, NFE and ash. Furthermore, broilers received multienzymes intermittently exhibited significantly better digestibility of CP than those given multienzyme continuously and the control group. There were no significant effects from the administration method on the apparent digestibility of DM, EE, CF and ash.

The present study indicates that the addition of multienzyme $100 \%$ intermittently to water improves the growth performance of broiler chickens compared with the control. The positive effect of enzymes on growth performance of broilers was observed along with considerable increasing in nutrient digestibility i.e. NFE and ash of this group. In addition, intermittently administration was adequate which may resulted in considerable saving in cost of additives. The present results are agreement with those reported by Zeng et al. (2015) and Alagawany et al. (2017). These improvements could be attributed to the increased digestive enzyme activities (Alagawany et al., 2017). Furthermore, these improvements could be also attributed to the eliminating the adverse impacts of anti-nutritional compounds and enhancing the availability and absorption of nutrients through increasing the digestibility of the ingested diets thereby improving growth performance of broilers (Attia 2003; Kocher et al., 2015 and Abdel-Hafeez et al., 2016). In addition, multienzyme was found to improve energy utilization in corn-soybean meal and sorghum-soybean meal diets because the digestion of starch and cereal cell walls (Attia et al., 2003 and Attia et al., 2008). However, the effect of multienzyme counted on dietary composition and enzyme type (Attia; 2003; Abudabos, 2012 and Attia et al., 2014a). 
Table (3): Effect of different dose of multienzymes given in water continuously or intermittently on apparent nutrient digestibility in broiler chicks ${ }^{1}$.

\begin{tabular}{|c|c|c|c|c|c|c|}
\hline \multirow[b]{2}{*}{ Treatment effect } & \multicolumn{6}{|c|}{ Apparent nutrients digestibility, \% } \\
\hline & Dry matter & $\begin{array}{c}\text { Crude } \\
\text { protein }\end{array}$ & $\begin{array}{l}\text { Ether } \\
\text { extract }\end{array}$ & $\begin{array}{l}\text { Crude } \\
\text { fiber }\end{array}$ & $\begin{array}{l}\text { Nitrogen } \\
\text { free extract }\end{array}$ & Ash \\
\hline \multicolumn{7}{|c|}{ Effect of enzyme dose } \\
\hline Control & $74.3 \mathrm{c}$ & $65.7 \mathrm{c}$ & $76.1 \mathrm{c}$ & 28.2 & 75.8 & 35.8 \\
\hline $100 \%$ & $77.0 \mathrm{a}$ & $70.9 \mathrm{a}$ & $80.5 \mathrm{a}$ & 30.4 & 77.9 & 37.7 \\
\hline $150 \%$ & $76.4 \mathrm{~b}$ & $69.8 \mathrm{~b}$ & $79.1 \mathrm{~b}$ & 30.4 & 78.0 & 37.4 \\
\hline \multicolumn{7}{|c|}{ Effect of administration method } \\
\hline Control & 74.3 & $65.7 \mathrm{c}$ & 76.1 & 28.2 & $75.8 \mathrm{c}$ & 35.8 \\
\hline Con & 76.8 & $69.6 \mathrm{~b}$ & 80.0 & 30.3 & $77.3 \mathrm{~b}$ & 37.4 \\
\hline Int & 76.6 & $71.0 \mathrm{a}$ & 79.6 & 30.5 & $78.6 \mathrm{a}$ & 37.7 \\
\hline \multicolumn{7}{|c|}{ Interaction between enzyme dose and administration method } \\
\hline Control & 74.3 & 65.7 & 76.1 & 28.2 & $75.8 \mathrm{c}$ & $35.8 \mathrm{c}$ \\
\hline $100 \%$ continuums & 77.2 & 70.2 & 80.4 & 30.5 & $77.8 \mathrm{a}$ & $38.1 \mathrm{a}$ \\
\hline $100 \%$ Int & 76.9 & 71.6 & 80.6 & 30.3 & $78.1 \mathrm{ab}$ & $37.4 \mathrm{ab}$ \\
\hline $150 \%$ continuums & 76.4 & 69.1 & 79.7 & 30.1 & $76.8 \mathrm{bc}$ & $36.8 \mathrm{bc}$ \\
\hline $150 \%$ Int & 76.3 & 70.4 & 78.5 & 30.7 & $79.2 \mathrm{ab}$ & $38.0 \mathrm{ab}$ \\
\hline RMSE & 0.892 & 0.960 & 1.059 & 0.812 & 1.539 & 1.397 \\
\hline \multicolumn{7}{|l|}{ Probability level } \\
\hline Dose & 0.0215 & 0.0010 & 0.0002 & 0.9384 & 0.8864 & 0.4529 \\
\hline Method & 0.4934 & 0.0001 & 0.1775 & 0.5121 & 0.0093 & 0.5227 \\
\hline Interaction & 0.6349 & 0.8189 & 0.0524 & 0.1471 & 0.0389 & 0.0386 \\
\hline
\end{tabular}

Con=Continuous; Int= intermittently

${ }^{1}$ Number of observation $=6$ replicates per subgroup of each treatments.

${ }^{\text {abc }}$ Within columns (for each effect), means not sharing similar superscripts are significantly different at $\mathrm{P}=0.05$.

Only the interaction between the dose of the multienzyme and the administration method had a significant effect on the digestibility of NFE and ash. Numerically, groups supplemented with either 100 or $150 \%$ multienzyme continuously or intermittently had significantly higher EE digestibility compared to the control group and group given 100\% enzymes intermittently had better EE digestibility than those given $150 \%$ enzyme intermittently. In addition, NFE and ash digestibility was significantly higher of enzyme supplemented groups than the control groups with the exception of those given $150 \%$ continuously. On the other hand, broilers received multienzyme at $100 \%$ continuously had higher digestibility of NFE and ash than groups received $150 \%$ enzyme by the same method.

\section{Carcass traits and inner body organs:}

The carcass characteristics and body organs of broiler chicks as affected by multienzyme and/or the method of administration are shown in Table (4).

The weight and percentages of dressing, abdominal fat, gizzard and proventriculus were not significantly affected by the dose of the enzyme, their method of administration, and the interaction between them with the exception of carcass weight with the administration method. However, groups supplemented with $150 \%$ multienzyme had higher weight and percentages of the intestinal (Table 4) and lower percentages of pancreas (Table 5) than the $100 \%$ multienzymes and control groups. Moreover, groups supplemented with $100 \%$ multienzyme had higher percentages of liver weight than the control. Furthermore, broilers who received multienzyme with continuously method exhibited significantly higher carcass weight, as well as percentages and weight of the intestinal and heart than those given at multienzyme with intermittently method. Moreover, broilers received enzymes at $150 \%$ continuously had higher percentages of the intestinal than other groups. 


\section{El-Shafey el al.}

Table (4): Effect of different dose of multienzymes given in water continuously or intermittently on some carcass characteristics and inner body organs in broiler chicks ${ }^{1}$.

\begin{tabular}{|c|c|c|c|c|c|c|c|c|c|c|}
\hline \multirow[b]{2}{*}{$\begin{array}{l}\text { Treatment } \\
\text { effect }\end{array}$} & \multicolumn{10}{|c|}{ Carcass and organs parameters } \\
\hline & $\begin{array}{l}\text { Carcass } \\
\text { weight, } \mathrm{g}\end{array}$ & $\begin{array}{l}\text { Dressing, } \\
\%\end{array}$ & $\begin{array}{l}\text { Abdominal } \\
\text { fat, } g\end{array}$ & $\begin{array}{l}\text { Abdominal } \\
\text { fat, } \%\end{array}$ & $\begin{array}{l}\text { Gizzard } \\
, \mathrm{g}\end{array}$ & $\begin{array}{l}\text { Gizzard } \\
, \%\end{array}$ & $\begin{array}{l}\text { Proventric } \\
\text { ulus, g }\end{array}$ & $\begin{array}{l}\text { ProventrIc } \\
\text { ulus, \% }\end{array}$ & $\begin{array}{l}\text { Intesti } \\
\text { nal, g }\end{array}$ & $\begin{array}{c}\text { Intestin } \\
\text { al,\% }\end{array}$ \\
\hline \multicolumn{11}{|c|}{ Effect of enzyme dose } \\
\hline Control & 1490 & 73.5 & 15.37 & 0.71 & 23.4 & 1.15 & 6.22 & 0.312 & $94.0 \mathrm{~b}$ & $4.66 b$ \\
\hline $100 \%$ & 1441 & 71.2 & 25.17 & 1.26 & 23.2 & 1.14 & 7.46 & 0.380 & $97.1 \mathrm{~b}$ & $4.78 b$ \\
\hline $150 \%$ & 1439 & 68.1 & 23.18 & 1.10 & 22.5 & 1.07 & 7.25 & 0.341 & $122 \mathrm{a}$ & $5.78 \mathrm{a}$ \\
\hline \multicolumn{11}{|c|}{ Effect of administration method } \\
\hline Control & $1490 \mathrm{~b}$ & 73.5 & 15.37 & 0.71 & 23.4 & 1.15 & 6.22 & 0.312 & $94.0 \mathrm{~b}$ & $4.66 b$ \\
\hline Con & $1523 \mathrm{a}$ & 71.0 & 25.03 & 1.16 & 24.5 & 1.14 & 7.47 & 0.351 & $122.2 \mathrm{a}$ & $5.73 a$ \\
\hline Int & $1358 \mathrm{c}$ & 68.4 & 23.32 & 1.19 & 21.2 & 1.08 & 7.24 & 0.367 & $96.9 \mathrm{~b}$ & $4.83 \mathrm{~b}$ \\
\hline \multicolumn{11}{|c|}{ Interaction between enzyme dose and administration method } \\
\hline Control & 1490 & 73.5 & 15.37 & 0.710 & 23.4 & 1.15 & 6.22 & 0.312 & 94.0 & $4.66 b$ \\
\hline $100 \%$ Con & 1550 & 71.3 & 24.82 & 1.13 & 25.7 & 1.19 & 7.40 & 0.350 & 104.4 & $4.80 \mathrm{~b}$ \\
\hline $100 \%$ Int & 1332 & 71.2 & 25.52 & 1.38 & 20.6 & 1.10 & 7.50 & 0.404 & 89.8 & $4.76 b$ \\
\hline $150 \%$ Con & 1495 & 70.7 & 25.24 & 1.19 & 23.2 & 1.10 & 7.520 & 0.352 & 140.0 & $6.66 a$ \\
\hline $150 \%$ Int & 1383 & 65.6 & 21.12 & 1.20 & 21.9 & 1.05 & 6.980 & 0.330 & 104.0 & $4.90 \mathrm{~b}$ \\
\hline RMSE & 167 & 3.58 & 5.85 & 0.262 & 3.69 & 0.177 & 1.247 & 0.063 & 15.636 & 0.645 \\
\hline \multicolumn{11}{|c|}{ Probability level } \\
\hline Dose & 0.979 & 0.071 & 0.457 & 0.198 & 0.711 & 0.400 & 0.732 & 0.229 & 0.002 & 0.002 \\
\hline Method & 0.039 & 0.119 & 0.521 & 0.821 & 0.065 & 0.428 & 0.706 & 0.587 & 0.002 & 0.005 \\
\hline Interaction & 0.485 & 0.139 & 0.369 & 0.079 & 0.253 & 0.784 & 0.584 & 0.205 & 0.142 & 0.007 \\
\hline
\end{tabular}

Con=Continuous; Int $=$ intermittently
${ }^{1}$ Number of observation $=6$ replicates per subgroup of each treatments.

${ }^{a b c}$ Within columns (for each effect), means not sharing similar superscripts are significantly different at $P=0.05$.

Our resulted showed that the weight and percentages of dressing, abdominal fat, gizzard and were not significantly affected by the dose of the enzymes, their method of administration, and the interaction between them. Based on these results, supplemental enzyme blend at the concentrations evaluated in this study may not exert drastic impacts on broilers. These results are in line with Mushtaq et al. (2009) who found no effect of enzyme supplementation on carcass traits. Also, De Araujo et al. (2014) and Alagawany et al. (2017) who found no effect of enzyme supplementation on carcass traits except liver percentage which was decreased with enzyme supplementation. Also, Rabie and Abo El-Maaty (2015) found that enzyme addition did not significantly affect carcass traits of Japanese quail. Attia et al. (2014b), Dalólio et al. (2016) and Al-Harthi (2017) reported that the parameters of carcass yield and carcass parts were not affected by the enzyme supplementation of diets fed to broiler chickens. These differences in carcass parameters of broiler chickens may be returned to composition and form of the diet as well as type and levels of enzymes used.

\section{Blood serum biochemical constituents and indices of liver and kidney functions:}

The results for serum indices of liver and kidney functions of the broiler chicks as they were affected by multienzyme supplementation and/or the administration method are shown in Tables (6 and 7). There were no significant effects from the multienzyme dose and the administration method on blood biochemical constituents and the serum indices of liver and kidney functions (Table 6) except for triglycerides, creatinine and HDL (Table 7). Broilers received multienzyme with continuously method exhibited significantly lower blood creatinine, but higher triglycerides and HDL than those given at multienzyme with intermittently method and the control group. Also, there were no significant differences in liver and renal functions indices due to the interactions between the dose of enzymes and the administration method except in ALT, alkaline phosphatase, urea, albumin, albumin/globulin ratio and triglycerides. 
Table (5): Effect of different dose of multienzymes given in water continuously or intermittently on inner body organs in broiler chicks ${ }^{1}$.

\begin{tabular}{|c|c|c|c|c|c|c|}
\hline \multirow{2}{*}{ Treatment effect } & \multicolumn{6}{|c|}{$\begin{array}{l}\text { Absolute weight }(\mathrm{g}) \text { and relative weight }(\%) \text { of carcass characteristics and inner } \\
\text { organ }\end{array}$} \\
\hline & $\begin{array}{c}\text { Liver } \\
\text { weight, } \mathrm{g}\end{array}$ & $\begin{array}{c}\text { Liver } \\
\text { weight, \% }\end{array}$ & $\begin{array}{l}\text { Pancreas } \\
\text { weight, g }\end{array}$ & $\begin{array}{r}\text { Pancreas } \\
\text { weight, \% }\end{array}$ & $\begin{array}{c}\text { Heart } \\
\text { weight, } g\end{array}$ & $\begin{array}{c}\text { Heart } \\
\text { weight, \% }\end{array}$ \\
\hline \multicolumn{7}{|c|}{ Effect of enzyme dose } \\
\hline Control & 39.7 & $2.00 \mathrm{~b}$ & 4.38 & $0.222 \mathrm{a}$ & 9.4 & 0.458 \\
\hline $100 \%$ & 48.1 & $2.39 \mathrm{a}$ & 4.37 & $0.221 \mathrm{a}$ & 10.1 & 0.491 \\
\hline $150 \%$ & 45.0 & $2.14 \mathrm{ab}$ & 3.59 & $0.169 \mathrm{~b}$ & 11.7 & 0.554 \\
\hline \multicolumn{7}{|c|}{ Effect of administration method } \\
\hline Control & 39.7 & 2.00 & 4.38 & 0.222 & $9.4 \mathrm{~b}$ & $0.458 \mathrm{~b}$ \\
\hline Con & 47.0 & 2.21 & 4.33 & 0.203 & $12.5 \mathrm{a}$ & $0.582 \mathrm{a}$ \\
\hline Int & 46.1 & 2.32 & 3.71 & 0.189 & $9.3 \mathrm{~b}$ & $0.463 \mathrm{~b}$ \\
\hline \multicolumn{7}{|c|}{ Interaction between enzyme dose and administration method } \\
\hline Control & 39.7 & 2.00 & 4.38 & 0.222 & 9.4 & 0.458 \\
\hline $100 \%$ Con & 1.19 & 2.21 & 4.52 & 0.212 & 12.6 & 0.576 \\
\hline $100 \%$ Int & 47.2 & 2.50 & 4.22 & 0.228 & 7.68 & 0.406 \\
\hline $150 \%$ Con & 45.1 & 2.10 & 4.10 & 0.193 & 12.4 & 0.588 \\
\hline $150 \%$ Int & 44.9 & 2.10 & 3.18 & 0.150 & 11.0 & 0.520 \\
\hline RMSE & 6.540 & 0.254 & 0.788 & 0.045 & 2.260 & 0.073 \\
\hline \multicolumn{7}{|c|}{ Probability level } \\
\hline Dose & 0.299 & 0.039 & 0.059 & 0.030 & 0.120 & 0.069 \\
\hline Method & 0.741 & 0.345 & 0.109 & 0.532 & 0.005 & 0.002 \\
\hline Interaction & 0.787 & 0.345 & 0.404 & 0.176 & 0.097 & 0.137 \\
\hline
\end{tabular}

Con=Continuous; Int = intermittently

${ }^{1}$ Number of observation $=6$ replicates per subgroup of each treatments.

${ }^{a b c}$ Within columns (for each effect), means not sharing similar superscripts are significantly different at $P=0.05$.

Broilers, who received $150 \%$ intermittently in water had lower ALT than other groups. In addition, broilers received $100 \%$ continuously and $150 \%$ intermittently in water, had higher alkaline phosphatase than the other groups. Moreover, broilers received $150 \%$ continuously in water, had lower urea than those given at 100\% continuously and control group, and higher albumin and triglycerides than the other groups. However, broilers received $150 \%$ continuously had the highest serum albumin.

In general, with a few exceptions, our results showed that there were no significant effects from the multienzymes dose and the administration method on the serum indices of liver and kidney functions and blood biochemical constituents. These results partially agree with Mehri et al. (2010) suggested that $\beta$ mannanase did not influence the blood serum proteins (albumin, alpha 1-, alpha 2-, beta and gammaglobulins). Also, Gheisari et al. (2011) showed that dietary enzyme treatments had no impact on serum protein concentrations. El-Katcha et al. (2014) observed that supplementation of enzyme had no significant effect on blood serum AST and ALT as well as cholesterol and triglyceride concentrations when compared with birds fed on the same diet without enzyme addition. Dinani et al. (2017) showed that enzyme supplementation had no significant on serum total protein, albumin, globulin and their ratio. Khaled et al. (2017) did not observe any significant ( $\mathrm{P}>0.05)$ effect of $\beta$-mannanse supplementation on serum alkaline phosphates, ALT, AST, uric acid and creatinine. Conversely to our results, Azarfar (2013) and Alagawany et al. (2017) who pointed out that the control diet resulted in significantly higher concentrations of total cholesterol and its fractions than the other diets which contained $1 \mathrm{~g}$ enzyme $/ \mathrm{kg}$. All blood serum parameters were not affected by enzyme supplementation (El-Serwy et al., 2012 and Fathey, 2012). 


\section{El-Shafey el al.}

Table (6): Effect of different dose of multienzyme given in water continuously or intermittently on indices of liver and kidney functions in broiler chicks ${ }^{1}$.

\begin{tabular}{|c|c|c|c|c|c|c|c|}
\hline \multirow[b]{2}{*}{$\begin{array}{l}\text { Treatment } \\
\text { effect }\end{array}$} & \multicolumn{7}{|c|}{ Indices of liver and renal function } \\
\hline & $\begin{array}{l}\text { ALT* } \\
\text { (U/L) }\end{array}$ & $\begin{array}{l}\mathrm{AST}^{* *} \\
(\mathrm{U} / \mathrm{L})\end{array}$ & $\begin{array}{l}\text { AST/ALT } \\
\text { ratio }\end{array}$ & $\begin{array}{l}\text { Alkaline } \\
\text { phosphatase } \\
\text { (U/L) }\end{array}$ & $\begin{array}{l}\text { Urea, } \\
\mathrm{mg} / \mathrm{dl}\end{array}$ & $\begin{array}{l}\text { Creatinine, } \\
\mathrm{g} / \mathrm{dl}\end{array}$ & $\begin{array}{l}\mathrm{U} / \mathrm{C} \\
\text { ratio }\end{array}$ \\
\hline \multicolumn{8}{|c|}{ Effect of enzyme dose } \\
\hline Control & 60.8 & 54.6 & 1.114 & 8.4 & 22.4 & 1.04 & 21.72 \\
\hline $100 \%$ & 60.6 & 54.2 & 1.118 & 9.6 & 21.9 & 1.01 & 22.28 \\
\hline $150 \%$ & 59.4 & 54.3 & 1.096 & 9.4 & 21.3 & 0.98 & 22.45 \\
\hline \multicolumn{8}{|c|}{ Effect of administration method } \\
\hline Control & 60.8 & 54.6 & 1.114 & 8.4 & 22.4 & $1.04 \mathrm{a}$ & 21.72 \\
\hline Con & 60.6 & 54.2 & 1.118 & 9.1 & 21.4 & $0.92 b$ & 23.73 \\
\hline Int & 59.4 & 54.3 & 1.096 & 9.9 & 21.8 & $1.07 \mathrm{a}$ & 21.01 \\
\hline \multicolumn{8}{|c|}{ Interaction between enzyme dose and administration method } \\
\hline Control & $60.8 \mathrm{a}$ & 54.6 & 1.114 & $8.4 \mathrm{~b}$ & $22.40 \mathrm{a}$ & 1.04 & 21.72 \\
\hline $100 \%$ Con & $60.0 \mathrm{a}$ & 53.6 & 1.118 & $10.4 \mathrm{a}$ & $22.40 \mathrm{a}$ & 0.92 & 24.92 \\
\hline $100 \%$ Int & $61.2 \mathrm{a}$ & 54.8 & 1.118 & $8.8 \mathrm{~b}$ & $21.40 \mathrm{ab}$ & 1.10 & 19.64 \\
\hline $150 \%$ Con & $61.2 \mathrm{a}$ & 54.8 & 1.118 & $7.8 \mathrm{~b}$ & $20.40 b$ & 0.92 & 22.54 \\
\hline $150 \%$ Int & $57.6 \mathrm{~b}$ & 53.8 & 1.074 & $11.0 \mathrm{a}$ & $22.20 \mathrm{ab}$ & 1.04 & 22.36 \\
\hline RMSE & 1.41 & 1.393 & 0.41 & 1.10 & 1.48 & 0.158 & 3.97 \\
\hline \multicolumn{8}{|c|}{ Probability level } \\
\hline Dose & 0.071 & 0.874 & 0.247 & 0.687 & 0.374 & 0.676 & 0.925 \\
\hline Method & 0.071 & 0.874 & 0.247 & 0.118 & 0.552 & 0.047 & 0.140 \\
\hline Interaction & 0.001 & 0.093 & 0.247 & 0.001 & 0.046 & 0.676 & 0.167 \\
\hline
\end{tabular}

Con=Continuous; Int = intermittently

${ }^{1}$ Number of observation $=6$ replicates per subgroup of each treatments.

${ }^{a b c}$ Within columns (for each effect), means not sharing similar superscripts are significantly different at $P=0.05$.

ALT* Alanine aminotransferase.

AST** Aspartate aminotransferase.

Table (7): Effect of different dose of multienzymes given in water continuously or intermittently on blood biochemical constituents of broiler chicks ${ }^{1}$.

\begin{tabular}{|c|c|c|c|c|c|c|c|c|c|c|}
\hline \multirow[b]{2}{*}{ Treatment effect } & \multicolumn{10}{|c|}{ Blood biochemical constituents } \\
\hline & $\begin{array}{l}\text { Total } \\
\text { protein, } \\
\text { g/dl }\end{array}$ & $\begin{array}{l}\text { Albumin, } \\
\text { g/dl }\end{array}$ & $\begin{array}{l}\text { Globulin, } \\
\text { g/dl }\end{array}$ & $\begin{array}{l}\mathrm{A} / \mathrm{G} \\
\text { ratio }\end{array}$ & $\begin{array}{l}\text { Total } \\
\text { lipids, } \\
\mathrm{mg} / \mathrm{dl}\end{array}$ & $\begin{array}{l}\text { Trigl, } \\
\text { mg/dl }\end{array}$ & $\begin{array}{l}\text { Chol., } \\
\text { mg/dl }\end{array}$ & $\begin{array}{l}\mathrm{HDL}, \\
\mathrm{mg} / \mathrm{dl}\end{array}$ & $\begin{array}{l}\mathrm{LDL}, \\
\mathrm{mg} / \mathrm{dl}\end{array}$ & $\begin{array}{l}\text { HDL/LDL } \\
\text { ratio }\end{array}$ \\
\hline \multicolumn{11}{|c|}{ Effect of enzyme dose } \\
\hline Control & 6.44 & 2.82 & 3.62 & 0.788 & 6.4 & 172.4 & 213.6 & 37.4 & 84.2 & 0.445 \\
\hline $100 \%$ & 6.21 & 2.92 & 3.28 & 0.910 & 9.5 & 172.4 & 211.9 & 36.4 & 83.6 & 0.436 \\
\hline $150 \%$ & 6.15 & 3.0 & 3.15 & 0.971 & 10.1 & 173.4 & 212.3 & 36.1 & 84.5 & 0.427 \\
\hline \multicolumn{11}{|c|}{ Effect of administration method } \\
\hline Control & 6.44 & 2.82 & 3.62 & 0.788 & 6.4 & $172.4 \mathrm{~b}$ & 213.6 & $37.4 \mathrm{a}$ & 84.2 & 0.445 \\
\hline Con & 6.11 & 3.01 & 3.09 & 0.990 & 9.4 & $174.0 \mathrm{a}$ & 212.0 & $37.7 \mathrm{a}$ & 84.6 & 0.446 \\
\hline Int & 6.25 & 2.91 & 3.34 & 0.881 & 10.2 & $171.8 \mathrm{~b}$ & 212.2 & $34.8 \mathrm{~b}$ & 83.5 & 0.417 \\
\hline \multicolumn{11}{|c|}{ Interaction between enzyme dose and administration method } \\
\hline Control & 6.44 & $2.82 \mathrm{~d}$ & 3.62 & $0.788 \mathrm{a}$ & 6.40 & $172.4 \mathrm{~b}$ & 213.6 & 37.4 & 84.2 & 0.444 \\
\hline $100 \%$ Con & 6.14 & $2.86 \mathrm{c}$ & 3.28 & $0.870 \mathrm{~b}$ & 9.0 & $172.4 b$ & 211.2 & 37.6 & 83.4 & 0.450 \\
\hline $100 \%$ Int & 6.26 & $2.98 b$ & 3.28 & $0.920 \mathrm{~b}$ & 10.0 & $172.4 \mathrm{~b}$ & 212.6 & 35.2 & 83.8 & 0.421 \\
\hline $150 \%$ Con & 6.06 & $3.16 \mathrm{a}$ & 2.90 & $1.10 \mathrm{~b}$ & 9.8 & $175.6 \mathrm{a}$ & 212.8 & 37.8 & 83.8 & 0.440 \\
\hline $150 \%$ Int & 6.24 & $2.84 \mathrm{c}$ & 3.40 & $0.840 \mathrm{~b}$ & 10.4 & $171.2 b$ & 212.8 & 34.4 & 83.2 & 0.413 \\
\hline RMSE & 0.205 & 0.194 & 0.300 & 0.130 & 0.980 & 1.86 & 3.95 & 2.87 & 2.41 & 0.036 \\
\hline \multicolumn{11}{|l|}{ Probability level } \\
\hline Dose & 0.591 & 0.367 & 0.345 & 0.237 & 0.186 & 0.245 & 0.823 & 0.817 & 0.414 & 0.601 \\
\hline Method & 0.117 & 0.262 & 0.078 & 0.077 & 0.083 & 0.016 & 0.911 & 0.034 & 0.320 & 0.092 \\
\hline Interaction & 0.745 & 0.019 & 0.078 & 0.016 & 0.653 & 0.016 & 0.505 & 0.699 & 0.179 & 0.941 \\
\hline
\end{tabular}

Con=Continuous; Int= intermittently; Trigl. = Triglycerides; Chol. $=$ Cholesterol $; H D L=H i g h$ density lipo-protein;

$L D L=$ Low density lipo-protein

${ }^{1}$ Number of observation $=6$ replicates per subgroup of each treatments.

${ }^{a b c}$ Within columns (for each effect), means not sharing similar superscripts are significantly different at $P=0.05$. 


\section{CONCLUSION}

Given the above, based on the results obtained in this study, it can be inferred that the inclusion of the multienzyme in broiler drink water, in the levels recommended by the manufacturer, $100 \%$, enhanced the efficiency of the growth performance and did not significantly influence the carcass characteristics and blood biochemical constituents. Furthermore, intermittent supplementation resulted in 50\% saving in the cost of additives.

\section{REFERENCES}

Abdel-Hafeez, H. M.; Saleh, E. S. E.; Tawfeek, S. S.; Youssef, I. M. I. and Abdel-Daim, A. S. A. (2016). Utilization of potato peels and sugar beet pulp with and without enzyme supplementation in broiler chicken diets: effects on performance, serum biochemical indices and carcass traits. J of Anim. Physiology and anim Nut., 102 (1): 56-66.

Abudabos, M. A.(2012). Phytate phosphorus utilization and intestinal phytase activity in laying hens. Italian J. of Anim. Sci., 11:e8 doi:10.4081/ijas.2012.e8.

Aggoor, F.A.; Attia, Y.A. and Qota, E.M. (2000). A study on thee nergetic efficiency of different fat sources and levels in broiler chick vegetable diets. J. of Agric. Sci., Mansoura University, 25:801-820.

Alagawany, M.; Attia, A. I.; Ibrahim, Z. A.; Mahmoud, R. A. and El-Sayed, S. A. (2017). The effectiveness of dietary sunflower meal and exogenous enzyme on growth, digestive enzymes, carcass traits, and blood chemistry of broilers. Environmental Sci. and Pollution Res. , 24(13):12319-12327. doi: DOI:10.1007/s11356-017-8934-4>

Al-Harthi, M. A. (2017). The effect of olive cake, with or without enzymes supplementation, on growth performance, carcass characteristics, lymphoid organs and lipid metabolism of broiler chickens. Brazilian J.1 of Poult. Sci., 19 (SPE), 83-90. https://doi.org/10.1590/1806-9061-2016-0311.

Angel, C. R.; Saylor, W.; Vieira, S. L. and Ward, N. (2011). Effects of a monocomponent protease on performance and protein utilization in 7- to 22-day-old broiler chickens. Poult. Sci., 90 (10): 22812286.

AOAC (2004). Association of Official Analytical Chemists. Official Methods of Analysis. $18^{\text {th }}$ ed., Washington, DC, USA.

Attia, Y. A. (2003). Performance, carcass characteristics, meat quality and plasma constituents of meat type drakes fed diets containing different levels of lysine with or without a microbial phytase. Archiv of Anim. Nut., 66: 39-48.

Attia, Y. A.; El-Tahawy, W. S.; Abd El-Hamid, A. E.; Nizza, A.; Bovera, F.; Al-Harthi, M. A. and ElKelway, M. I. (2014a). Effect of feed form, pellet diameter and enzymes supplementation on growth performance and nutrient digestibility of broiler during days 21-37 of age. Archiv Tierzucht, 57, 3:, 111. doi: 10.7482/0003-9438-57-034. https://www.arch-anim-breed.net/57/34/2014/.

Attia, Y. A.; El-Tahawy, W. S.; Abd El-Hamid, A. E.; Nizza, A.; El-Kelway, M. I.; Al-Harthi, M. A. and Bovera, F. (2014b). Effect of feed form, pellet diameter and enzymes supplementation on carcass characteristics, meat quality, blood plasma constituents and stress indicators of broilers. Archiv

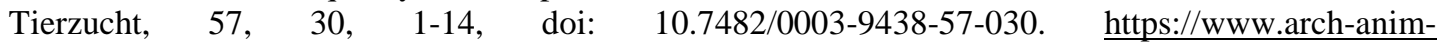
breed.net/57/30/2014/.

Attia, Y. A.; Tag El-Din, A. E.; Zeweil, H. S.; Hussein, A. S.; Qota, E. M. and Arafat, M. A. (2008). The effect of supplementation of enzyme on laying and reproductive performance in Japanese quail hens fed nigella seed meal. The J. of Poult. Sci., 45:110-115. https://www.jstage.jst.go.jp/article/jpsa/45/2/45_45_110/article/-char/en

Attia, Y.A.; Qota, E. M. A.; Aggoor F. A. M. and Kies, A. K. (2003). Value of rice bran, its maximal utilization and upgrading by phytase and other enzymes and diet- formulation based on available amino acid for broiler chicks. Archiv Für Geflügelkunde, 67 (4):157-166. https://www.europeanpoultry-science.com/artikel.dll/s-157-166_NzgwNQ.PDF. 


\section{El-Shafey el al.}

Azarfar, A. (2013). Effect of hemicell enzyme on the performance, growth parameter, some blood factors and ileal digestibility of broiler chickens fed corn/soybean-based diets. J. of Cell and Anim. Biology., 7:85-91

Bartles, H.; Bohmer, M. and Heierli, C. (1972). Serum creatinine determination without protein precipitation. Clinica Chimica Acta, 37: 193-197.

Coles, E. H. (1974).Veterinary clinical pathology. IST ED. 211-213 W.B. Saunder, company, Philadelphia, London, Toronto.

Costa, F. G. P.; Goulart, C. C.; Figueiredo, D. F.; Oliveira, C. F. S. and Silva, J. H. V. (2008). Economic and environmental impact of using exogenous enzymes on poultry feeding. Inter. J. of Poult. Sci., 7: 311-314.

Cowieson, A.( 2010). Strategic selection of exogenous enzymes for corn/soy-based poultry diets. J. Poult. Sci., 47(1):1-7.

Dalólio, F. S.; Moreira, J.; Albino, L. F. T.; Vaz, D. P.; Pinheiro, S. R. F.; Valadares, L. R. and Pires, A. V. (2016). Exogenous enzymes in diets for broilers. Revista Brasileira de Saúde e Produção Animal, Salvador, 17(2): 149-161. http://dx.doi.org/10.1590/S1519-99402016000200003.

De Araujo, W.; Albino, L. F. T.; Rostagno, H. S.; Hannas, M. I.; Pessoa, G. B. S.; Messias, R. K. G.; Lelis, G. R. and Ribeiro, V. Jr.( 2014). Sunflower meal and enzyme supplementation of the diet of 21 to 42-d-old broilers. Brazil J. of Poult. Sci., 16:17-24.

Dinani, O. P.; Tyagi, P. K.; Tyagi, P. K.; Mandal A.B. and Jaiswal, S. K. (2017). Effect of feeding fermented guar meal vis-ÀVis toasted guar meal with or without enzyme supplementation on immune response, caeca micro flora status and blood biochemical pparameters of broiler quails international. J Pure Applied Bioscience. 5 (1): 624-630 (2017) ISSN: 2320 -7051.

Doumas, B. (1971). Colorimetric determination of serum albumin. Clinica Chimica Acta, 31: 400-403.

Duncan, D.B.(1955). Multiple range and multiple "F" test. Bio- metrics, 11:1-42.

El-Katcha, M. I.; Soltan, M. A.; El-Kaney, H. F. and Karwarie, E. R. (2014). Growth performance, blood parameters, immune response and carcass traits of broiler chicks fed on graded levels of wheat instead of corn without or with enzyme supplementation. Alex. J. of Vet. Sci., 40:95-111. doi: $10.5455 /$ ajvs.48232.

El-Serwy, Amina A., Shoeib, M. s. and Fathey I. A. (2012). Performance of broiler chicks fed mash or pelleted diets containing corn-with-cobs meal with or without enzyme supplementation. J. of Anim. and Poult. Prod., Mansoura University., Vol.3 (3): 137-155.

Fafiolu, A. O.; Oduguwa, O. O.; Jegede, A. V.; Tukura, C. C.; Olarotimi, I. D.; Teniola, A. A. and Alabi, J. O. (2015). Assessment of enzyme supplementation on growth performance and apparent nutrient digestibility in diets containing undecorticated sunflower seed meal in layer chicks. Poult. Sci.,, 94(8): 1917-1922, https://doi.org/10.3382/ps/pev136.

Fathey, I. A. (2012). Nutritional studies on poultry. Ph. D. thesis, Faculty of Agriculture Mansoura University, Egypt.

Fossati, P. and Prencipe, L. (1982). Serum triglycerides determined colorimetrically with an enzyme that produces hydrogen peroxide. Clinical chemistry, 28: 2077-2080.

Friedewald, W. T.; Levy, R. I. and Frederickson, D. S. (1972). Estimation of the concentration of lowdensity lipoprotein cholesterol in plasma without use of the preparative ultracentrifuge. Clinical chemistry, 18: 499-502.

Gheisari, A. A.; Shavakhi, Zavareh M.; Toghyani, M.; Bahadoran, R. and Toghyani, M. (2011). Application of incremental program, an effective way to optimize dilatory inclusion rate of guar meal in broiler chicks. Livestock Sci., 140 (1-3): 117 - 123.

Henry, R.; Cannon, D. and Winkelman, J. (1974). Clinical chemistry, principles and techniques, $2^{\text {nd }}$ edition, Harper and Row, New York, USA.

Hooge, D. M.; Pierce, J. L.; Mcbride, K.W. and Rig olin, P. J. (2010). Metaanalysis of broiler chicken trials using diets with or without allzyme SSF enzyme complex. Inter. J. of Poult. Sci., 9 (9):819-823. 
Khaled, N. E.; Ragaa, N. M.; Tony, M. A. and El-Banna, R. A. (2017). Effect of dietary inclusion of guar meal with or without $\beta$ mannanase supplementation on broiler performance and immunity. Pakistan $\mathrm{J}$. of Nut., 16: 341-350.

Kocher, A.; Hower, JM and Moran, C.A (2015). A dual enzyme product containing protease in broiler diet: efficacy and tolerance. J. of Applied Anim. Nut., 3: 1-14 https://doi.org/10.1017/jan.2015.4

Lopez-Virella, M. F.; Stone, S.; Eills, S. and Collwel, J. A. (1977). Determination of HDL-cholesterol using enzymatic method. Clin. Chem., 23: 882-884.

Mehri, M.; Adibmoradi, M.; Samie, A. and Shivazad, M. (2010) Effects of Mannanase on broiler performance, gut morphology and immune system. African J. of Biotec., Vol. 9 (37), pp. 6221-6228.

Mushtaq, T.; Sarwara, M.; Ahmad, G.; Mirza, M. A.; Ahmad, T.; Mushtaq, M. M. H. and Kamran, Z. (2009). Influence of sunflower meal based diets supplemented with exogenous enzyme and digestible lysine on performance, digestibility and carcass response of broiler chickens. Anim. Feed Sci. and Tec., 149:275-286.

NRC (1994). National Research Council, Nutrient requirement of poultry. National Academy Press, Washington, DC, USA.

Rabie, M. H. and Abo El-Maaty, H. M. A. (2015) Growth performance of Japanese quail as affected by dietary protein level and enzyme supplementation. Asian J. of Anim. and Vet. Advances, 10:74-85

Reitman, S. and Frankel, S. (1957). A Method for determination of enzymatic activities. American Journal of Clinical Pathology, 287: 56-58.

SAS Institute (2002). SAS/STAT User's guide statistics. SAS institute INC., Cary. NC, USA.

Slominski, B. A. (2011). Recent advances in research on enzymes for poultry diets. Poult. Sci., 90:20132023.

Stein, E. A. (1986). Quantitative enzymatic colorimetric determination of total cholesterol in serum or plasma. In: Textbook of Clinical Chemistry. N. W. Tietz, editor. WB. Saunders, Philadelphia, USA Pp. 879-886.

Trinder, P. (1969). Enzymatic colorimetric determination of glucose in serum, plasma or urine. Ann. of Clin. Biochem, 6: 24-26.

Williams, M. P.; O’Neil, H. V. M.; York, T. and Lee, J. T. (2018). Effects of nutrient variability in corn and xylanase inclusion on broiler performance, nutrient utilisation, and volatile fatty acid profiles. $\mathrm{J}$. of Applied Anim. Nut., 6:e1. https://doi.org/10.1017/jan.2017.11

Williams, M. P.; Klein, J. T.; Wyatt, C. L.; York, T. W. and Lee, J. T. (2014). Evaluation of xylanase in low-energy broiler diets. J. of Applied Poult. Res., 23:188-195.

Yegani, M. and Korver, D. R. (2013). Effects of corn source and exogenous enzymes on growth performance and nutrient digestibility in broiler chickens. Poult. Sci., 92:1208-1220.

Zeng, Q.; Huang, X.; Luo, Y.; Ding, X.; Bai, S.; Wang, J.; Xuan, Y.; Su, Z.; Liu, Y. and Zhang, K. (2015). Effects of a multi-enzyme complex on growth performance, nutrient utilization and bone mineralization of meat duck. J. of Anim. Sci. and Biotec., 6-12. DOI 10.1186/s40104-015 


\section{El-Shafey el al.}

الأداء الإنتاجي و هضم العناصر الغذائية والصفات الكيميائيه للام فى كتاكيت التسمين وتأثرها بجر عه وطريقه اضافه الأنزيمات

علي سعيد الشافعي1 ، أسماء شوقي النجار 1 و محمود إبراهيم الكيلاوي 2 1 قسم الانتاج الصيوانسي والد/جني - كليه الزراعة - جامعه دمنهور - مصر. 2 قسم انتاج الدواجن -كليه الزراعة - جامعة الوادي الجبلي - مصر.

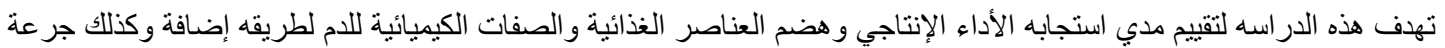

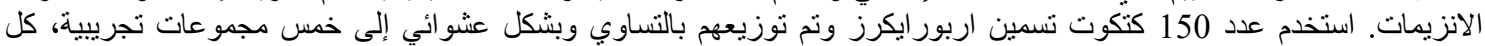

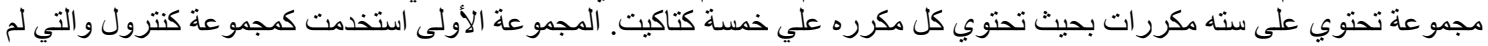

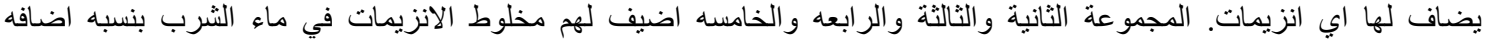

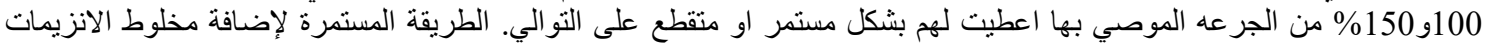

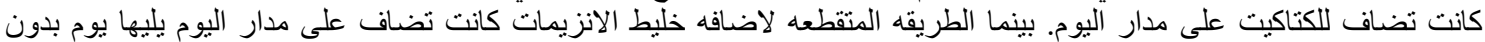

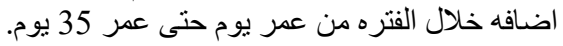

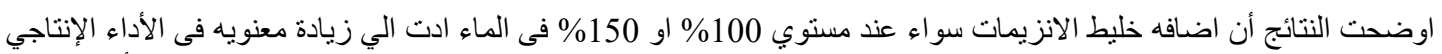

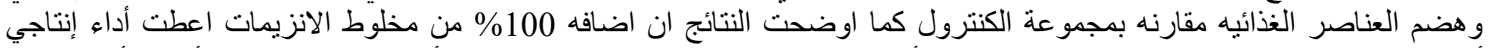

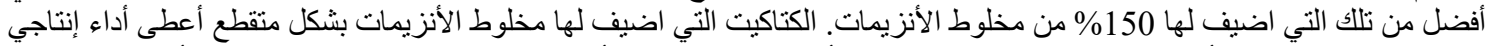

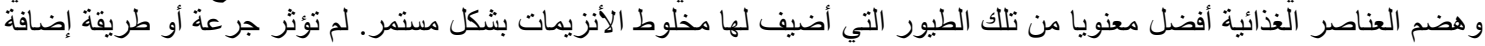

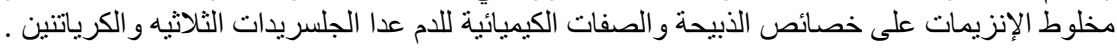

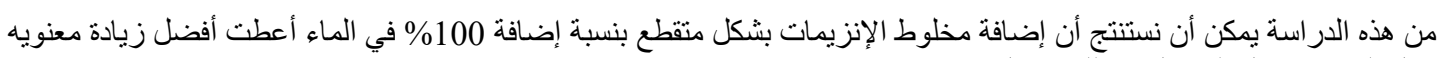
فى معدل النمو ومعامل التحويل وكذللك معامل الإنتاج. 